\title{
Health and Safety Concerns Related to CNT and Graphene Products, and Related Composites
}

\author{
Susana P.B. Sousa ${ }^{1}$, Tânia Peixoto ${ }^{2,3}$, Raquel M. Santos ${ }^{1,4}$, Ascensão Lopes ${ }^{2}$, \\ Maria da Conceição Paiva ${ }^{3}(\mathbb{D})$ and António T. Marques ${ }^{2,4, * \mathbb{C}}$ \\ 1 Institute of Science and Innovation in Mechanical and Industrial Engineering, 4200-465 Porto, Portugal; \\ ssousa@inegi.up.pt (S.P.B.S.); rmsantos@inegi.up.pt (R.M.S.) \\ 2 Faculdade de Engenharia da Universidade do Porto, 4200-465 Porto, Portugal; \\ tania_peixoto23@hotmail.com (T.P.); malopes@fe.up.pt (A.L.) \\ 3 Institute for Polymers and Composites, University of Minho-Campus of Azurém, 4800-058 Guimarães, \\ Portugal; mcpaiva@dep.uminho.pt \\ 4 Associated Laboratory for Energy, Transports and Aeronautics-INEGI, 4200-465 Porto, Portugal \\ * Correspondence: marques@fe.up.pt; Tel.: +35-12-2048-3477
}

Received: 1 July 2020; Accepted: 29 July 2020; Published: 4 August 2020

\begin{abstract}
The use of Carbon Nanotubes (CNT) and Graphene increased in the last decade and it is likely to keep increasing in the near future. The attractiveness of their properties, particularly the possibility to enhance the composites performance using a tailor made methodology, brings new materials, processes and products for highly demanding industrial applications and to the market. However, there are quite a lot of health/safety issues, as well as lack of understanding and standards to evaluate their effects. This paper starts with a general description of materials, processes and products dealing with CNT and graphene. Then, an overview of concerns related to the health and safety when handling, researching, producing and using products that include these materials is presented. It follows a risk management approach with respect to simulation and evaluation tools, and considering the consensual limits already existing for research, industry and consumers. A general discussion integrating the relevant aspects of health and safety with respect to CNT and graphene is also presented. A proactive view is presented with the intention to contribute with some guidelines on installation, maintenance, evaluation, personal protection equipment (PPE) and personnel training to deal with these carbon-based nanomaterials in research, manufacture, and use with composite materials.
\end{abstract}

Keywords: CNT; graphene; health; safety; risk management; composite materials

\section{Introduction}

In this century, the field of nanotechnology has risen to the forefront of research and development, standing out the carbon nanoallotropes. The specific and excellent properties of CNTs and graphene pave the way to an ever-increasing number of applications, such as medical devices and drugs, energy, environment, biology, aerospace, aeronautics, automotive, sports, electronics, solar cells, structural batteries, adhesives, composites, polymers, super capacitors, ultra-stiff materials, gas sensors, biosensors, wastewater treatment, reinforced rods, mechanical memories, coatings, and films [1-6]. In fact, they present high tensile strength and modulus, high thermal and electrical conductivities, high absorbency and aspect ratio and low weight, which means that these nanomaterials have very high specific properties. However, the health and safety implications of Engineered nanomaterials-ENM, including CNT and graphene, are far away from being understood and full of uncertainties. In fact, the high exposures are likely to cause harm to the researchers in laboratories, workers in industrial 
production sites or in the waste, recycling industries, consumers, and environment [3-5,7]. Therefore, it is essential to assess the short, medium and long-term effects and potential risks [8,9].

Both academic laboratories and industries, where the work in the field of nanotechnology is very active, it is particularly important to prevent and mitigate the risks associated with the handling, producing and transforming nanomaterials by establishing laboratory procedures and guidelines to avoid unexpected and unnecessary concerns $[9,10]$. Decision makers, researchers, production and maintenance workers must evaluate risks and take the precautionary measures to have a safer working atmosphere [11]. Nanosafety must be considered in the development phase, covering the total life cycle, ensuring that nanotechnology may provide answers to society needs [12]. The aim of this paper is to contribute to these goals.

Starting with a brief description of materials, processes and final products that deal with CNT and graphene, the paper presents the more relevant health and safety concerns before going to the risk assessment methodologies. After a general discussion, we move to a proactive view where some guidelines will be addressed.

To develop the proposed work a holistic review was performed based on diverse bibliography concerning the health and safety issues related to CNT and graphene products, mainly on the reported literature from 2000 to 2020. The literature review was carried out using search engines, and other databases, with the following search strategy: combination of the keywords and sub-keywords; selection of the relevant articles by reading the title and abstract; and, full text reading of the selected articles. After selecting the items, a critical analysis was performed.

\section{State of the Art Review}

The main aim of this systematic review was to evaluate briefly the state of art of the health and safety concerns related to CNT and graphene products, including composite systems with these nanomaterials.

Therefore, firstly in this section, the use of nanomaterials will be described, how they are produced and processed to yield a product with enhanced properties, following a systematic review related to the ENM and their applications.

Secondly, an overview of concerns related to the health and safety when handling, researching, producing and using products that include these nanoengineered materials is presented, bearing in mind exposure in occupational operations and end users practices.

At last, the risk management approaches are presented in terms of simulation and evaluation tools for research, industry and consumers' management.

\subsection{Materials}

Different types of carbon engineered nanomaterials derived from graphene (Figure 1) can be considered: fullerenes, carbon nanotubes, graphene and their derivatives [13]. They have attracted worldwide applications (energy, aeronautics, environment, biology, medicine, etc.), due to their unique properties that make them promising candidates for a wide range of applications. 


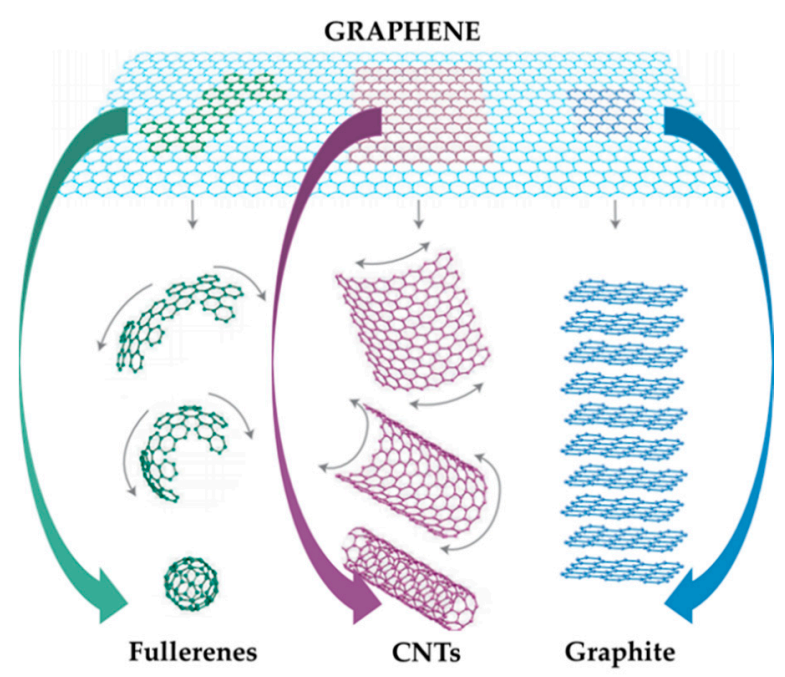

Figure 1. Relation between graphene and other carbon allotropes, adapted from [13].

Figure 1 shows graphene as the building block of all graphitic carbon allotropes with different dimensionalities [13].

Carbon-based nanomaterials can appear with different aspects and morphologies, such as hollow tubes, ellipsoids, platelets or spheres [1]. Fullerenes, such as $\mathrm{C}_{60}$, carbon nanotubes (CNTs), carbon nanofibers (CNFs), carbon black and graphene are all included under the carbon-based nanomaterials category [14]. These are considered of particular interest as nanoreinforcements to the Carbon Fibre Reinforced Polymer (CFRP) composites community, showing the ability to improve their global performance, as can be seen in Table 1 [2].

Table 1. Some changes induced by the carbon nano allotropes addition to CFRP.

\begin{tabular}{|c|c|c|c|}
\hline Type & $\phi^{\mathrm{a}}(\mathrm{nm})$ & Content (wt. \%) & Relevant Property Improvements \\
\hline $\begin{array}{c}\text { Carbon } \\
\text { Nanofibres }\end{array}$ & $\begin{array}{l}60 \text { to } 200 \\
\sim 200\end{array}$ & 2.0 & $\begin{array}{c}+22 \% \text { Flexural strength } \\
+11 \% \text { Tensile strength } \\
+4 \% \text { Glass transition temperature [15] } \\
+79 \% \text { Impact absorption energy } \\
+42 \% \text { Inter-laminar shear strength } \\
+14 \% \text { Flexural strength [16] }\end{array}$ \\
\hline $\begin{array}{c}\text { Multiwalled } \\
\text { carbon nanotubes }\end{array}$ & $\begin{array}{l}10 \text { to } 20 \\
\quad \sim 10 \\
30 \text { to } 50\end{array}$ & $\begin{array}{l}0.3 \\
0.5 \\
0.3\end{array}$ & $\begin{array}{c}+25 \% \text { Flexural strength [17] } \\
+3 \% \text { Tensile strength [18] } \\
+53 \% \text { Flexural modulus [19] }\end{array}$ \\
\hline Graphene & $\begin{array}{l}8 \\
5\end{array}$ & $\begin{array}{l}0.1 \\
0.4\end{array}$ & $\begin{array}{c}+11 \% \text { Fracture toughness [20] } \\
+19 \% \text { Tensile modulus } \\
+18 \% \text { Tensile strength } \\
+19 \% \text { Flexural modulus } \\
+15 \% \text { Flexural strength }[21] \\
+19 \% \text { Interlaminar Shear Strength } \\
+26 \% \text { Flexural modulus }\left(90^{\circ}\right) \\
+82 \% \text { Flexural strength }\left(90^{\circ}\right) \\
+4 \% \text { Flexural modulus }\left(0^{\circ}\right) \\
+7 \% \text { Flexural strength }\left(0^{\circ}\right) \\
+167 \% \text { Electrical conductivity }[22]\end{array}$ \\
\hline
\end{tabular}

a Average diameter or length/thickness. 
The Single Wall Carbon Nanotubes (SWCNTs) and Multi-Walled Carbon Nanotubes (MWCNTs) may have similar lengths, ranging from hundreds of nanometers to tenths of micrometers, although they have also different diameter ranges. The SWCNTS have typical diameters between 1 and $3 \mathrm{~nm}$, whilst MWCNTs range from 10 to $200 \mathrm{~nm}$. Similarly, graphene flakes present thicknesses of one carbon atom while their lateral dimensions may vary from hundreds of nanometers to hundreds of microns. From graphene to a few-layer graphene and graphite, flakes with increasing thickness are also available. The size and shape aspects of these nanoparticles should be accounted for assessing health and safety issues $[1,3,11,14,23]$.

The CNTs and CNFs are available as liquid dispersions, dry powders or embedded in polymers as nanocomposites or CFRP composites [23]. For many applications, it is necessary to modify and functionalize the CNTs surface, aiming at ensuring a better compatibility and a stronger interface between the nanofiller and the polymeric matrix.

\subsection{Processes}

The combination between the remarkable structural performance of continuous carbon fibres $(\mathrm{CFs})$ with the multifunctional properties of carbon-based nanomaterials allows the development of novel nanoengineered (multiscale) CFRP composites (Figure 2) with interesting synergies [1].

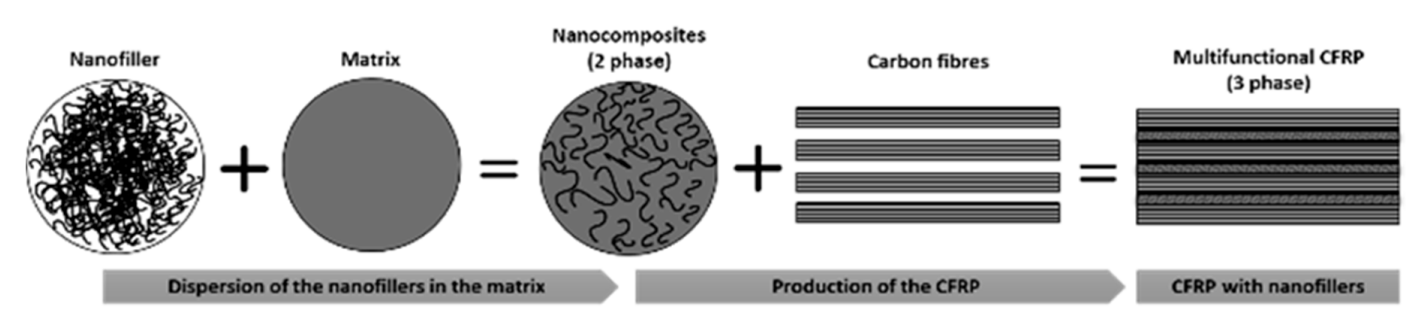

Figure 2. Typical scenario of the production of a multifunctional CFRP by incorporating nanofillers [1].

The combination of carbon-based nanoreinforcements with conventional fibre reinforcements in polymer composites may be achieved through different routes, namely, dispersing in the polymer matrix, growing on fibres, interleaving buckypapers and stitching the nanomaterials onto the fibres [24].

There have been various approaches to improve the dispersion and the interaction between the carbons-based reinforcements and the thermoset polymers, which can be divided into two main categories of chemical and mechanical approach. The chemical approach focuses on the creation of chemical bonding between the nanotubes and the polymer matrix. The chemical approach includes: (1) the creation of non-covalent bonding by the solvent and surfactant-assisted dispersion, and (2) the creation of covalent bonding by the surface functionalization of the nanomaterials. While the mechanical approach mainly employs the sophisticated mixing methods (Figure 3), such as: (1) dispersing the particles into the matrix with the help of sonication and or (2) by high shear mixing (three-roll milling) [25-30]. 

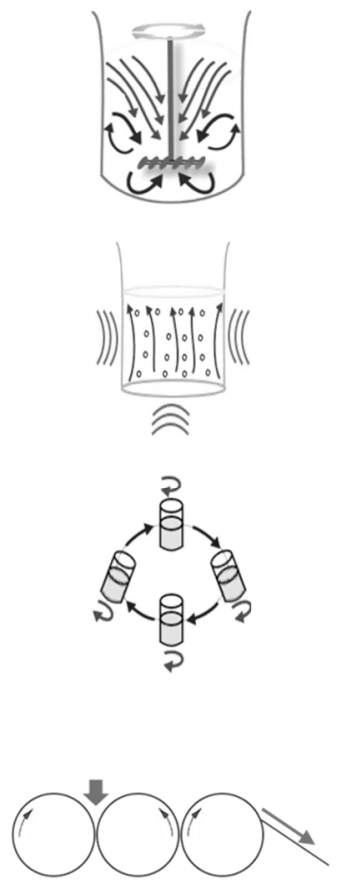

Mechanical/ shear mixing

- Parameters: speed, time and temperature

- Advantages: break up aggregates

- Disadvantages: air entrapment and foamy mixtures

Ultrasonication

- Parameters: frequency, power intensity, time and temperature

- Advantages: fine dispersion and degassing

- Disadvantages: ineffective for high viscous mixtures and if the temperature is not controlled the matrix can react before the expected

\section{Centrifugation}

- Parameters: rotor speed, temperature and time

- Advantages: enhance dispersion and reduce air entrapment

- Disadvantages: inadequate speed can produce aggregates and voids

Three-roll milling

- Parameters: gap size, temperature, roller speed and pressure

- Advantages: easy to obtain an uniform distribution of the nanomaterials in the matrix and does not need a control temperature system because the temperature to remain low despite the high amount

- Disadvantages: due to the large open area of the equipment causes loss of volatiles/nanoparticles to the work environment

Figure 3. Main physical methods to disperse nanomaterials, created from [28-30].

In order for the nano modified thermosetting polymers to penetrate into the primary fibre tows, filtration effects need to be minimized, usually by using low loading fractions and small/short nanomaterials to produce the hybrids composites. Manufacturing processes for advanced composites include methods such as hand lay-up, resin transfer moulding (RTM), compression moulding, filament winding, autoclave curing, vacuum-assisted resin transfer moulding (VARTM), among others. Some of these advanced fabrication techniques enable structural composites to be manufactured with better compaction and low void fractions and, in turn, superior mechanical and other properties. Nevertheless, manufacture of high performance composites using nano modified prepregs with autoclave curing has been "the gold standard" established by aerospace industry [31,32]

Melt-mixing routes are commonly used to prepare CNT-polymer and graphene-polymer nanocomposites within the thermoplastics industry, making them available at large scale. Typically, the polymer nanocomposites are produced by twin-screw extrusion and are available in the form of pellets, ready for the application in industrial processes, as injection moulding, extrusion blow molding, filament drawing, among others [33].

\subsection{Products}

The typical properties of conventional CFRPs, including high stiffness, strength-to-weight ratio, fatigue tolerance and electrical conductivity are strongly dependent on the CFs orientation. After the great success of manufacturing high performance CFRP, scientists have continued exploring the world of carbon-based materials, since the out-of-plane properties of composites are mainly dominated by the insulating and brittle nature of the thermoset or more ductile thermoplastic polymers [1]. Hence, the modification of these polymeric matrices with carbon allotropes has proved to overcome some of those limitations [34]. Through the incorporation of nanomaterials, at ultralow percolation thresholds, advanced, lightweight and smart CFRPs with integrated novel functionalities have been successfully developed [35]. These nanostructures have brought various extraordinary properties such as electrical, mechanical, thermal and "smart" properties [36-39]. For example, the formation of a conductive network established between the well dispersed carbon-based nanomaterials within 
polymeric matrices allows the communication and interaction with the surrounding environment, and the response accordingly to the external stimuli (self-sensing) [26].

At present, information of CNT and graphene products that are already on the market are listed in the inventory compiled by StatNano [40]. In this database a total of 172 products are listed containing these nano carbon allotropes (Figure 4), for a diverse range of applications, among which health and fitness products constitute the largest category. In addition, it is reported that companies based in the United States share more than $43 \%$ of the total products, followed up by UK with $40 \%$. It is also possible to observe a large number of research papers and patents from the aerospace, aeronautics, automotive, defence, medical and construction industries related with CNTs and graphene, the main investigation focus being the enhancement of specific properties and/or providing functionalities to a given product [40].

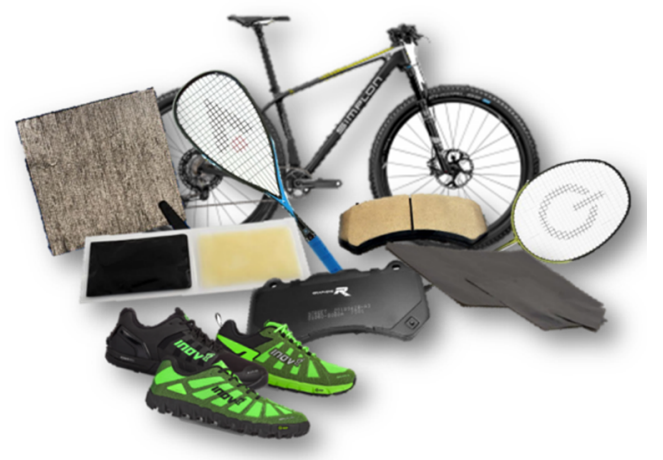

Figure 4. Some examples of the CNT and Graphene products that are already on the market, created from [40].

\subsection{Health}

From early nanotoxicological studies, it became apparent that, due to their unique physicochemical properties, nanomaterials behaved differently from common chemicals. In fact, most of the nanoparticles are insoluble by nature and, at the same time, they can be dispersed and remain stable within a solution [41]. So, the health and safety concerns about the different types of carbon nanoparticles have been addressed for almost two decades, however consensus on this topic is still far from being reached [5,42].

These nanoscale materials present low bulk density, constituting a safety hazard even when used in small quantities for research purposes (in the order of $\mu \mathrm{g}, \mathrm{mg}$ or $\mathrm{g}$ ). Due to their nanoscale size, these particles may remain suspended in the air for considerable time. For example, their open-air handling can promote the material loss to the atmosphere (environment) and result in potentially harmful exposure, either by dermal contact or inhalation, to researchers and workers $[10,43,44]$. In fact, the uptake of nanoparticles by inhalation has been described as one of the main routes for contamination of lab workers, which in the long-term may result in breathing problems or even create more serious diseases [43-45].

In general, humans are likely to be exposed to effects of nanoparticles from nanoengineered materials also by ingestion, apart from inhalation and skin uptake [46]. Depending upon the manufacturing and processing techniques, CNTs and graphene are likely to be a concern for human health, as they can be released to the environment by several mechanisms, including wear and abrasion of the final product. They may cause dermal effects, inflammation, mutagenesis, interstitial fibrosis, lung tumours and vascular effects (Figure 5) [23,47-49]. In addition, these nanoparticles may access the central nervous system by the following routes $[49,50]$ :

1. Systemic-affecting semi permeable barriers (blood-brain and blood-spinal cord) of the central nervous system.

2. Olfactory neurodegenerative diseases—due to the direct brain delivery of particles. 
3. Trigeminal-the route uses the trigeminal nerve as an important way to transport from nose to brain, i.e., intracellular or axonal transport.

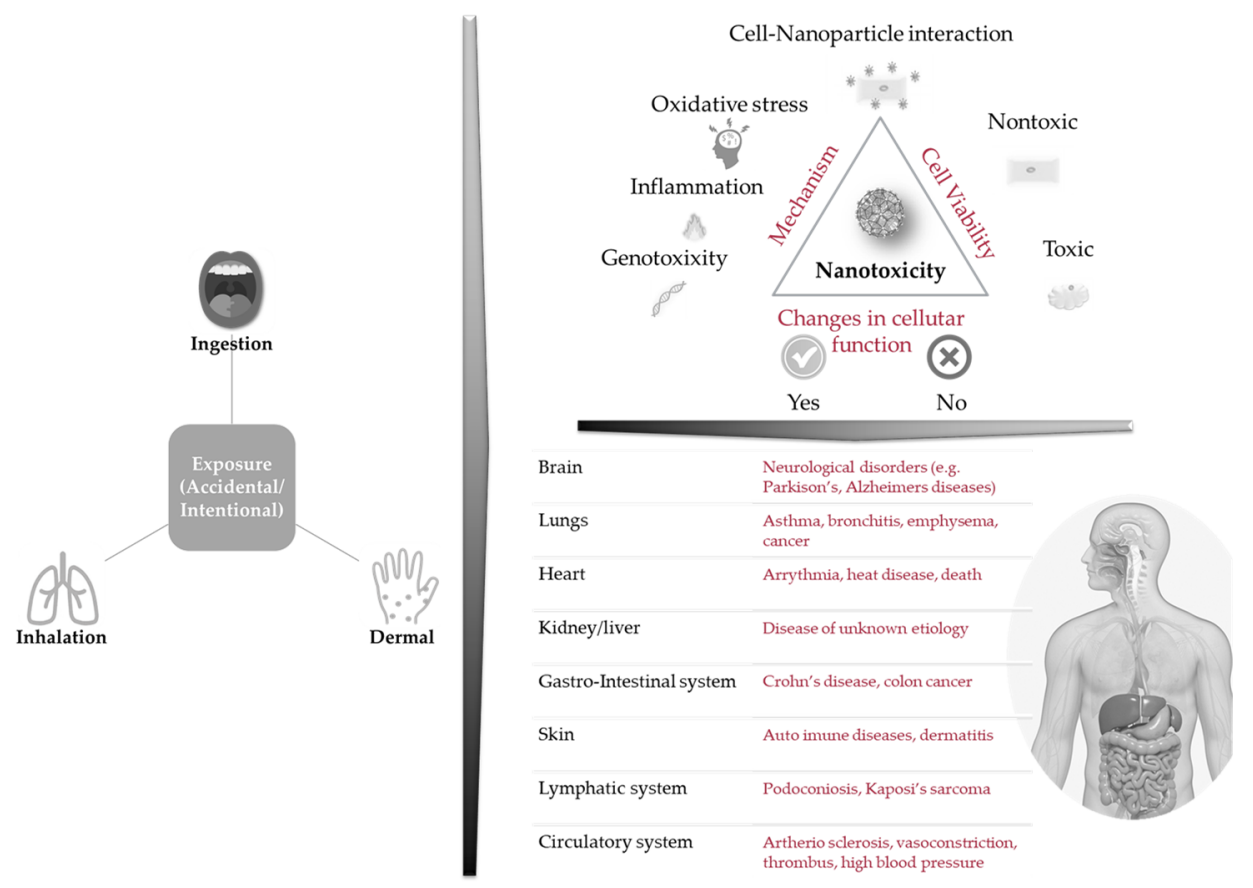

Figure 5. Potential interactions of carbon nano allotropes and possible consequences, created from [49].

The CNTs induce toxicity, such as oxidative damage in biological systems and influence the central nervous system, trough endothelial cell damage [46]. Additionally, due to the batch-to-batch variations nanoengineered materials parameters may change with time, implying possible changes in the toxicological effects (Figure 6). This means that CNTs and graphene need to be fully characterized, in short and long term, and have a specific toxicity (eco) assessment, as well as rendering hazard and risk evaluation $[41,47,51]$.

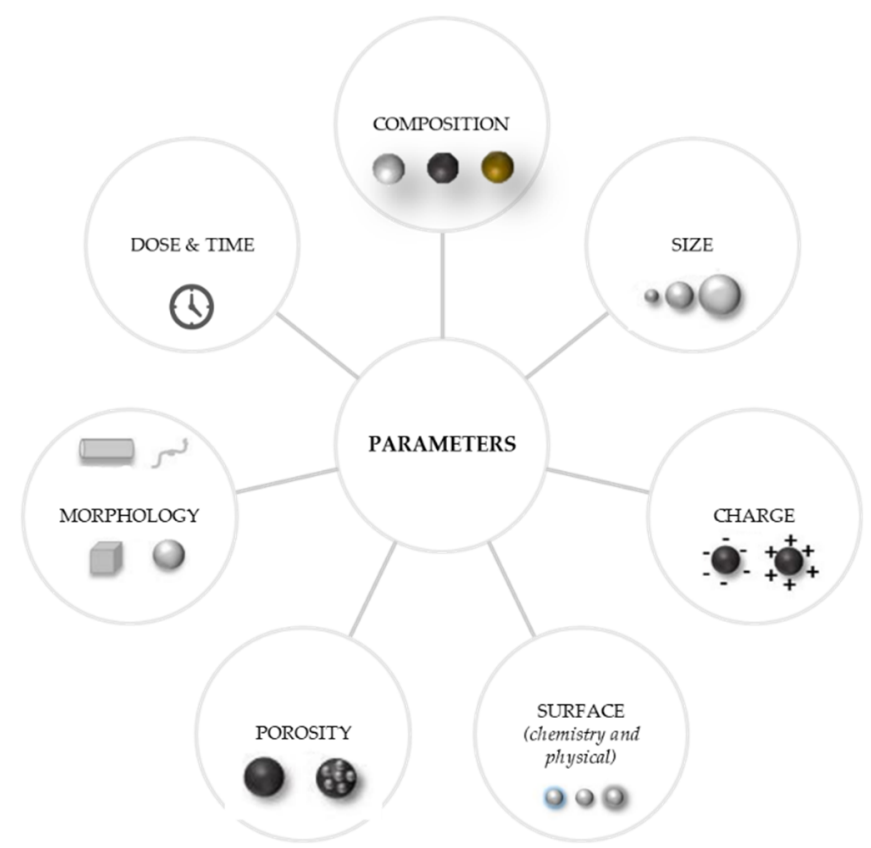

Figure 6. Key properties involved in nanotoxicity, created from [41]. 
Vascular effects induced by CNTs have been reported through different mechanisms. It may cause progression of atherosclerotic plaque, changes in blood pressure and heart rates, as well as vasomotor dysfunctions [52]. However, these drawbacks are more common with pristine CNTs, since functionalization may lead to less damage effects.

\subsection{Safety}

The production of CNT, graphene and other derivatives, their chemical functionalization, as well as the modification of polymers and CFRPs, by incorporating these nanomaterials, leads to different levels of the workers' exposure. From the synthesis to the different applications with the downstream nanoparticle use for further dispersion and processing into products, or surface treatment, different forms of exposure (e.g., powder, liquid and "solid" states) are involved [1].

Preventive safety measures must be applied to all workers (i.e., researchers, engineers, technicians, chemists and even managers) that are involved in the different phases of the production of CFRPs with carbon nano allotropes, although considering different levels of exposure [23]. A clear definition for limit levels of exposure is necessary for each role in the process, for each nanomaterial and for each process route. Moreover, the increasing evidence that people already with respiratory diseases are likely to be more susceptible to damage effects [53,54], for safety reasons the exposure limits and the likelihood of a person to work with nanoengineered materials need to be objectively evaluated. Safety data sheets must be provided for the life cycle of all nanoengineered materials [55]. They must include product, hazards, company identification, and safety exposure limits. The determination of Occupational Exposure Limits (OEL) [11] and users' limits are of paramount importance. Although admitting incertitude, some recommended exposure levels were presented, namely $1 \mu \mathrm{g} / \mathrm{m}^{3}$ elemental carbon in a respiratory mass 8-h time-weighted average (TWA) concentration [56], but the knowledge in this area still does not ensure nanotechnology safety [57].

Accounting for the considerations above, it can be stated that for safety purposes, scientific and technical studies must be done to answer the following questions [58]:

- How to overcome limitations of current technologies and techniques?

- What are the most important physical and chemical properties with respect to biological behavior of ENM, in short, medium and long time?

- What should be the degree of accuracy and how to measure accurately?

- What are the ignition and explosive properties, and their potential risks?

It has been stated [58] that Personal Protection Equipment (PPE), if used properly, may be an effective way to reduce damage risks when dealing with ENM.

\subsection{Risk Management}

Naturally, a well-defined risk management evaluation requires the identification and characterization of the hazards type expected to occur, exposure assessment and potential risks. Although there are some common features for ENM, in general, a methodology for a given group of ENM may not be adequate for another one. Hence, it is important to clearly characterize the nanomaterial and its potential hazards. Volume Specific Surface Area (VSSA) together with the nanoparticle size have been reported as complementary criterion for their definition [59].

Exposure to nanomaterials, particularly to ENM, can occur under research activities during production (with release of nanoparticles to air and water), handling, during service applications subjected to diverse ageing effects and product end of life, with possible re-use, recycling, waste treatment and final disposal. For those reasons, the integration of Life Cycle Analysis (LCA) into risk assessment is highly recommended. In this context, the milestones indicated in Table 2 are expected to be reached by 2025 [12]. 
Table 2. Risk prediction and management tools for 2025, adapted from [12].

\begin{tabular}{|c|c|c|}
\hline Milestone & Topic & 2025 \\
\hline \multirow[t]{2}{*}{ Risk assessment (RA) } & $\begin{array}{l}\text { Proactive risk } \\
\text { management }\end{array}$ & $\begin{array}{l}\text { With the use of risk banding tools and } \\
\text { effective control measures development } \\
\text { practice in 201, high throughput screening } \\
\text { approaches will be validated by } 2020\end{array}$ \\
\hline & Tools & $\begin{array}{l}\text { RA-enabled LCA/Integration } \\
\text { into decision tools }\end{array}$ \\
\hline $\begin{array}{l}\text { Epidemiology and } \\
\text { health surveillance }\end{array}$ & $\begin{array}{l}\text { Health effect } \\
\text { Register } \\
\text { Study design }\end{array}$ & $\begin{array}{l}\text { Implementation of the markers } \\
\text { Implementation of results for regulations } \\
\text { Longitudinal studies started }\end{array}$ \\
\hline Databases & $\begin{array}{l}\text { Infrastructure } \\
\text { Ontologies }\end{array}$ & $\begin{array}{l}\text { IT procedures for automatic uploading } \\
\text { Automatization of ontologies }\end{array}$ \\
\hline \multirow[b]{2}{*}{ Risk management } & Risk perception and guidance & Guidance on risk evaluation \\
\hline & $\begin{array}{l}\text { Prevention through } \\
\text { design approach }\end{array}$ & $\begin{array}{l}\text { Integration of safe-by-design approaches } \\
\text { into development stages of new NMs and } \\
\text { their applications }\end{array}$ \\
\hline
\end{tabular}

Aiming to ensure the health and safety of workers, employers have the obligation to conduct regular risk assessments—as specified in the "Framework" Directive 89/391/EEC—in every aspect related to their work, particularly when dealing with ENM. Moreover, the Directive 98/24/EC on chemical agents at work imposes stricter rules for work risk management regarding these substances-particularly, the hierarchy of prevention measures that strengthens elimination or substitution as priority measures. This can also be applied to nanomaterials, as they fall within the definition of "substances" [60].

There is no specific legislation applicable to nanoparticles (NP) and nanomaterials. Some International Organization for Standardization (ISO), American Society for Testing and Materials (ASTM International) and British Standards Institution (BSI Group) standards applied to these materials are beginning to emerge. In the traditional risk assessment, the exposure doses are compared to the occupational exposure limit values (OELs). Since there are no specific OELs for NP, these standards propose, as a pragmatic orientation, the limit values shown in Table 3 [60].

Table 3. OELs for nanomaterials (NM) [60].

\begin{tabular}{cc}
\hline \multicolumn{1}{c}{ Description } & Benchmark Exposure Levels \\
\hline Fibrous; a high aspect ratio insoluble NM & 0.01 fibres $/ \mathrm{ml}$ \\
\hline $\begin{array}{c}\text { Any NM which is already classified in its molecular or in its larger } \\
\text { particle form as carcinogenic, mutagenic, reproductive toxin or as } \\
\text { sensitizing (CMRS) }\end{array}$ & $0.1 \times$ OEL \\
\hline Insoluble or poorly soluble NM not in the fibrous or CMRS category & $0.066 \times$ OEL \\
\hline Soluble NM not in the fibrous or CMRS category & $0.5 \times$ OEL \\
\hline
\end{tabular}

In addition, the World Health Organization has issued guidelines for the protection of workers to minimize risks when dealing with nanomaterials [61].

\subsubsection{Risk Assessment Methods}

Risk assessment involves solving equation 1 and can be evaluated by using semi-quantitative analyses. Recommended values have been issued by several institutions, such as the French Agency for Food, Environmental and Occupational Health \& Safety method (ANSES), from France; Control Banding Nanotool (CB Nanotool), from the United States of America-National Institute for Occupational Health and Safety (NIOSH); École Polytechnique Fédérale de Lausanne method (EPFL), 
from Switzerland; Guidance working safely with nanomaterials and nanoproducts (GWSNN), from The Netherlands; Istituto Superiore per la Prevenzione e la Sicurezza del Lavoro (ISPESL), from Italy; Precautionary Matrix for Synthetic Nanomaterials (PMSN), from Switzerland; and Stoffenmanager Nano, from The Netherlands [62].

$$
\text { Risk }=\text { Hazard } \times \text { Exposure }
$$

Table 4 shows an overview of hazard factors defined by each method for a given situation [62].

Table 4. Hazard band factors [62].

\begin{tabular}{ccccccc}
\hline Hazard Factor & ANSES & $\begin{array}{c}\text { CB } \\
\text { Nanotool }\end{array}$ & EPFL & GWSNN & ISPESL & PMSN Stoffenmanager \\
\hline $\begin{array}{c}\text { Toxicity (nano and/or } \\
\text { bulk material) }\end{array}$ & $\bullet$ & $\bullet$ & $\bullet$ & $\bullet$ & $\bullet$ \\
\hline Solubility & $\bullet$ & $\bullet$ & $\bullet$ & $\bullet$ & $\bullet$ & $\bullet$ \\
\hline $\begin{array}{c}\text { Fibre form } \\
\text { (particle shape) }\end{array}$ & $\bullet$ & $\bullet$ & $\bullet$ & $\bullet$ & $\bullet$ & $\bullet$ \\
\hline Reactivity & $\bullet$ & & $\bullet$ & $\bullet$ \\
\hline Size & & $\bullet$ & & $\bullet$ \\
\hline Fire and explosion & & & & & $\bullet$ \\
\hline
\end{tabular}

Other nanomaterial grouping approaches can be obtained in BSI [63], NIOSH [64] and BAuA-The Federal Institute for Occupational Safety and Health [65].

In Table 5 the factors that could determine the worker's exposure are presented.

Table 5. Exposure (or likelihood) band [62].

\begin{tabular}{|c|c|c|c|c|c|c|c|}
\hline Exposure Factor & ANSES & $\begin{array}{c}\text { CB } \\
\text { Nanotool }\end{array}$ & EPFL & GWSNN & ISPESL & PMSN & Stoffenmanager \\
\hline Quantity & & $\bullet$ & $\bullet$ & & & $\bullet$ & $\bullet$ \\
\hline $\begin{array}{l}\text { Duration/ frequency } \\
\text { (time) factor }\end{array}$ & & • & & & • & • & • \\
\hline $\begin{array}{l}\text { State of material } \\
\text { (e.g., solid, liquid) }\end{array}$ & • & & • & & & & • \\
\hline $\begin{array}{c}\text { Release of } \\
\text { nano-objects } \\
\text { (e.g., dustiness) }\end{array}$ & $\bullet$ & • & & $\bullet$ & & $\bullet$ & $\bullet$ \\
\hline $\begin{array}{l}\text { Aggregation/ } \\
\text { agglomeration }\end{array}$ & & & • & & $\bullet$ & & \\
\hline
\end{tabular}

REACH [66] and ECHA [67] may be considered as the most updated documents regarding regulations and guidance for nanomaterials grouping [51]. Risk estimation and characterization is defined by REACH [66] and comparing exposure and hazard levels provides the estimate of a Risk Characterization Ratio, defining process categories versus environmental risk categories. It also presents an overview of selected risk assessment tools [68].

\subsubsection{Research}

Nanotechnologies present new challenges regarding risk evaluation and management. Hence, besides technological developments, research has to be performed for risk evaluation based upon quantitative data on toxicology and ecotoxicology, and, when necessary, adjusting the assessment 
methodology [69]. Answering to future disruptive scientific and technical challenges in nanoscience's and nanotechnologies, while keeping in mind health and safety concerns, is essential to ensure the competitiveness and economic growth.

\subsubsection{Industry}

Dealing with polymeric nanocomposites processing requires a safety analysis and preventing risks, which is the base of the Framework Directive 89/391/EEC. Health and safety at the workplace is the main driver of this Directive, implying that risk assessments regularly made by the employer. However, there is nothing specific for nanomaterials. Thus, the suitability of the legal framework is uncertain or even speculative. Being chemistry involved, nanomaterials are likely to be considered under the chemicals regulations [60].

A proper legal framework is barely needed in order to regulate the use of NM, and ensure confidence from cradle to grave [70]. Beyond consistency and avoiding market distortions, harmonized regulations will guarantee risk minimization and ensure workers' health and environmental safety.

\subsubsection{Application}

Even embedded in a matrix, nanoparticles release can occur during all stages, i.e., from cradle to grave. The probability of exposure must be analysed for the entire life cycle of the nanomaterial, being the risks evaluation made applying a model close to the one use for natural disasters [60]. Up to now, there are few and limited detailed risk or life cycle studies on the specific impacts of nanomaterials. Moreover, the waste must be removed from the system following specific protocols; once the cleaning operation is finished, all waste has to be stored in appropriate containers for further disposal control [69,71,72].

Prevention is the main action to mitigate possible risks related to nanoparticles and this can start in the design phase, followed by the safety in the manufacturing process and safe procedures for the use of the products.

Risk assessment and management must be considered in a life cycle approach and include the effect of specific nanomaterials in several environmental situations such as air (can nanoparticles with $<70 \mathrm{~nm}$ pass through HEPA filters), landfill, waste incineration, sewage and sewage treatment plants and water $[58,73,74]$.

\section{Discussion}

CNTs and graphene are valuable raw materials with numerous application in several sectors, yet legitimate concerns about their potential adverse effects on human and environmental health and safety need to be addressed. CNTs, due to their morphology (fibre type) have higher potential to be harmful than other carbon particles forms (i.e., spherical and plates). They can have a higher contact area with the cell membrane in comparison with particles of different shapes. CNTs are considered hazardous when thinner than $3 \mu \mathrm{m}$ and longer than $\sim 20 \mu \mathrm{m}$, or when no biodegradation in the lungs by dissolving or breaking is possible. Moreover, below these dimensions, there is also a clear evidence for pulmonary and intraperitoneal carcinogenicity of bio persistent nanofibres, and certain MWCNTs $[1,75]$. Pulmonary fibrosis has also been highlighted as an effect of MWCNT exposure [76,77]. For graphene, however, there are only few studies that have assessed its toxicity, evidencing that some forms of this nanomaterial can be a health hazard $[47,78,79]$.

The workers' exposure to health risks might occur during production, downstream use for further processing or dispersion into products, and application or treatment of CNT/graphene modified CFRPs. During the CFRPs production carbon-based nanomaterials can pass through different "states" (powder, in a liquid resin and inserted into the solidified polymeric matrix), leading to different exposure degrees, as can be seen in Figure 7 [1]. 


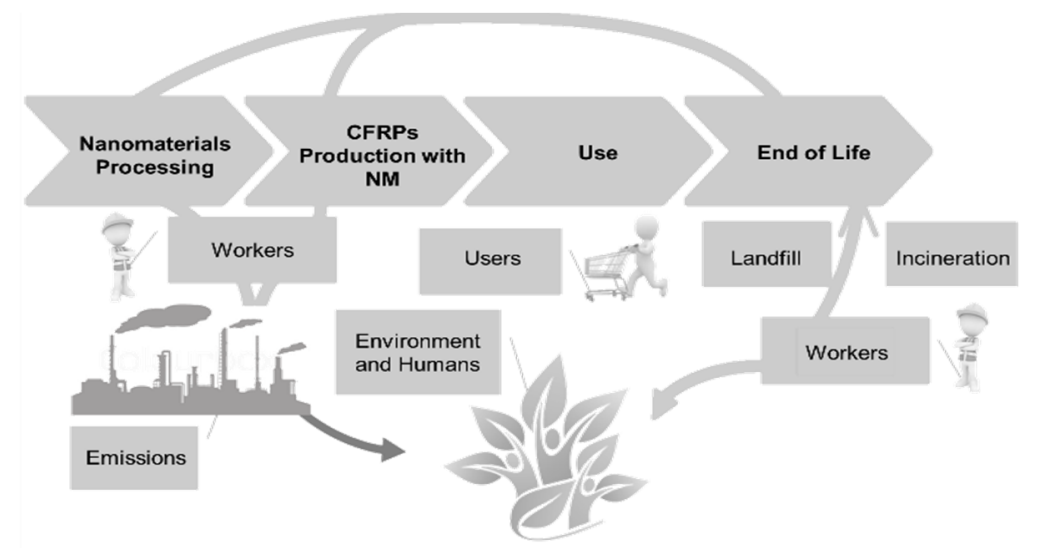

Figure 7. Possible exposures during life-cycle of CFRP's modified with carbon allotropes [1].

Polymeric materials, including NC, are considered chemicals. Hence, some of the legislation related to chemical agents and REACH (Registration, Evaluation, Authorisation and Restriction of Chemicals) applied [60].

The Organization for Economic Co-operation and Development (OECD) has recommended the application of existing international and national chemical regulatory frameworks to deal with the risks associated with manufactured nanomaterials (NM). Protocols that have been applied to chemicals (based on legal frameworks for these products) can be applicable to NM [80].

The actual regulation is normally supported on parameters likely to be unsuitable for some nanotechnology applications. For example, thresholds are often defined in terms of production volumes or mass, below which a substance may be exempt from regulation. These thresholds should be reviewed and, when appropriate, modified. But, while specific NP regulations are not established, proactive approaches must be followed [60].

It has been reported [46] that the use of CNTs in neurology can only be made in a safer way, if they have a high degree of purification, are well tailored and properly coated.

Costs are always an issue related to health and safety. Although health and safety are normally regarded as cost raisers, the evaluation must be done with a holistic approach. In fact, the reduction of production costs must not be used at expenses of safety. Nanosafety must be included in the development phase, giving guidance to the technology selection and subsequent improvement of safety and sustainability [33]. To have a global picture of the calculation of final cost for safety, a list of the main parameters has $[46,73]$ been designed and must be implemented. Although not exhaustive, the following list can be considered, by order of importance:

1. Employees,

2. Identification and compliance with regulations,

3. Risk and vulnerability analysis,

4. Emergency response plans, related drills and training,

5. Personnel training, refreshments, role compliance monitoring,

6. Maintenance, inspection and monitoring of equipment and instrumentation,

7. Fire and explosion protection,

8. Personal protection equipment,

9. Investigation of incidents and near misses,

10. Hazardous material transportation,

11. Alarms and control equipment,

12. Passive barriers,

13. Construction of code-certified buildings,

14. Costs related to raw materials, 
15. Costs of equipment,

16. Insurance cost,

17. Security cost,

18. Decommissioning costs,

19. Software related costs.

An effective health and safety program will reduce potential incidents and, consequently, worker's compensation insurance costs [74].

Healthy and safety from cradle to grave will ensure safe innovations in nanomaterials and products. Nanosafety strategies must start by information gathering to achieve risk mitigation, followed by hazard and exposure assessment, risk characterization and monitoring [68]. There is no consensus regarding safe occupational exposure limits for specific CNTs. However, $50 \mathrm{mg} / \mathrm{m}^{3}$ is indicated [3] as limit concentration based on risk estimation of noncancerous adverse lung effects. A recommended exposure limit-REL for a working life of 45 years is referred to be $1 \mu \mathrm{g} / \mathrm{m}^{3}[56,81]$. Moreover, the proposed occupational exposure limit-OEL for CNTs is suggested to be in the range of 1 to $50 \mu \mathrm{g} / \mathrm{m}^{3}$ as an 8 hours' time weighted average-TWA $\mu \mathrm{g} / \mathrm{m}^{3}$ [56]. NIOSH also recommends a REL $1 \mu \mathrm{g} / \mathrm{m}^{3}$ for 8-h TWA of exposure to CNTs and CNFs of respirable carbon element [56,81].

From the general review, several authors suggested that the application of the precautionary principle can be used as a guideline in the environmental decision making process [81].

It is accepted, in general, that CNTs have higher potential to be harmful than other carbon particles shapes (i.e., spherical and plates), due to higher contact area with the cell membrane in comparison with other particle shapes. They are considered hazardous when below $3 \mu \mathrm{m}$ diameter and longer than $\sim 20 \mu \mathrm{m}$, or when no biodegradation in the lungs by dissolving or breaking is possible. Besides that, below these dimensions, there is also clear evidence for pulmonary and intraperitoneal carcinogenicity of bio persistent nanofibers, and certain MWCNTs. Furthermore, pulmonary fibrosis has been highlighted as an effect of MWCNT exposure [33,76,82].

The production of goods incorporating carbon nanomaterials involve the workers' exposure during the nanomaterials production, downstream use for further processing or dispersion into matrix materials, and application or treatment to form the final products. Along the different stages of carbon-based nanomaterials processing and handling, different exposure degrees are attained.

It should be noted that besides human impacts, the carbon-based nanomaterials also exhibit toxicity to plants, other animals and microbes [83-85].

Eliminating the risk at source by replacing the potentially hazardous substances by safer ones appears to be an attractive and cost-effective solution; however, it is hard to apply since the CNTs and graphene-based products have unique properties desired by the industry.

\section{Proposals}

Exact exposure assessment methods for nanoparticles have not yet been established, and the occupational exposure limits for carbon-based nanomaterials have not been set, leading to inconclusive results and sometimes to inadequate protection measures [33,76,82].

A guidance on the protection of the health and safety of workers from the potential risks related to nanomaterials at work from the European Commission is available for safe practices [86]. Different universities, as well as research labs, have also provided guides on their websites for working with nanomaterials, which mainly involve following standard protocols similar to those existent for other materials with known or uncertain toxicity, whose goal is mainly to prevent any type of exposure $[87,88]$.

In this section, a proactive view is proposed aiming to contribute with general guidelines on technical, maintenance, evaluation, personal protection (PPE) equipment and personnel training to deal with CNT and nano graphene products in research, manufacturing and use with composite materials. 


\subsection{Technical}

Technical measures comprise the infrastructures, construction of buildings, warning systems, installations and building layout. These measures are designed and implemented in the building, to ensure the collective protection of the workers, against multiple risks that may affect their health or safety at work.

The effect of the controls can be expressed as the protection factor (PF). It is defined as the ratio of exposure level (either mass-based or particle-based) without the controls divided by the exposure level with the controls (PF > 1 controls reduce exposure; a PF of 10 indicates that controls reduce exposure by $90 \%)[61]$.

\subsubsection{Laboratory}

By using appropriate equipment and proper lab practices, it is possible to reduce the risks associated with the manipulation of nanomaterials $[43,89]$.

The recommended technical protective measures in the laboratories are the following [90]:

- Ventilation:

With renewal without recycling $5-10 \times / \mathrm{h}$,

- With at least a sealed F7/H14 filter (EN 779) for exiting air, since these filters have $80-90 \%$ average efficiency for $0.4 \mu \mathrm{m}$ particles,

$\bigcirc \quad$ Low pressure room,

- Capture of the contaminate air at the source.

- A seamless and impermeable resin floor with coving between the floor and wall will minimize the risk of accumulation in cracks and gaps of nanomaterials, by making at the same time easier to clean and easily remove contaminants from the area.

- Manipulation under fume hood (compulsory).

- $\quad$ SAS entrance and exit (simple).

- Safety shower.

\subsubsection{Industry}

The recommended technical protective measures should be almost the same that are used in the laboratory, although it must be ensured that the low-pressure room is $>20 \mathrm{mPa}$ and that the SAS entrance and exit is double [90].

For SMEs (Small and Medium Size Enterprises), costs of some controls may become highly expensive, if not prohibitive. Hence, these companies should consider alternatives out of their organization as a strategy to follow controls within a restricted budget, such as [74]:

- Cooperation with academia and/or larger companies to have access to a high level of controls.

- Consider the acquisition of used laboratory equipment, but bear in mind to ensure they operate under the correct specifications prior to use.

- Work with local economic and development groups to promote the importance of engineering controls as enabler tools for nanotechnology commercialization for SMEs and promoting the benefits of protecting workers, environment and community at large.

- Include discussion of EHS - Environmental Health and Safety rules in the business plan and budget for high-level of controls possible needed.

Moreover, SMEs should consider the possibility to share, among themselves, high-level of controls equipment. 


\subsection{Personal Protection Equipment}

Personal protection equipment (PPE) are devices or appliances designed to be used by an individual worker for his protection against one or more health and safety hazards. When working with nanomaterials the personal protective equipment should be preferably disposable, however, when it is not possible it must be cleaned regularly or after use [84].

The principle of hierarchy of controls suggests that the first control measure should be to eliminate the source of exposure. This will reduce implementing control measures that are more dependent on workers' attitudes. Involvement with PPE should be used only as a last resource. In the absence of appropriate engineering controls PPE should be used, especially respiratory protection, as part of a respiratory protection programme, including fit-testing [61].

\subsubsection{Laboratory}

Laboratories typically involve shorter work periods and exposure to smaller quantities of nanomaterials. Hence, the PPE that should be adopted is $[84,85,90,91]$ :

- Masks with P3 filters are advised for respiratory protection.

- To protect the eyes/face, use a face shield or lab goggles.

- Protection of the body parts with overalls with hood (Tyvek ${ }^{\circledR}$ style), since nonwoven clothing is more efficient against penetration of NP than woven cotton.

- The use of two or more pairs of disposable gloves (nitrile, vinyl, latex, Neoprene ${ }^{\circledR}$ ) should be adopted and frequently replaced, especially for exposure to nanomaterials in liquid phase.

There are indispensable considerations and recommendations for the handling and disposal of nanomaterials, including graphene and related derivatives.

Regarding their handling, research and working personnel should always wear appropriate clothing and PPE, which include lab coats, gloves, well-fitted masks and appropriate eye protection $[8,89,92]$. These materials should be in sealed containers, stored in closed cabinets and samples' size should be limited to small amounts and manipulated carefully, in order to avoid spills and lower the risk of dermal exposure and the risk of airborne contamination [8,89]. Special considerations during weighting or synthesis processes should also be undertaken. Free particles should not be manipulated on the lab bench. Opening up sample recipients and weighing processes should be carried out under a fume hood or at least in a glove box dedicated to that process $[8,89,93]$. Although the risk of exposure is higher when handling powders than when working with dispersions [10], these should also be contained, particularly if subjected to ultrasonication. Furthermore, these particles should not be disposed of as general waste but should be bagged, labelled as nanoscale, and sent out for authorized authorities as hazardous waste. If dispersed, the medium should first be neutralized if it is the case and should be disposed of according to the hazardous chemical waste guidelines $[8,89,93]$. Adequate cleaning procedures are also necessary. Work areas should be cleaned after use or at a minimum at the end of each day. Any small powder spills should be removed by using wet wiping methods. The contaminated surface should be cleaned until no trace of nanomaterial is visible. Larger spills should be cleaned with a vacuum cleaner equipped with a HEPA filter. Research laboratories should be routinely cleaned and checked regularly to ensure the maintenance of cleanliness. In addition, all devices and equipment meant to prevent or eliminate work hazardous materials should undergo maintenance and be checked regularly $[8,92,93]$. The regular realization of particle surveys is also important to quantify any airborne particle contamination, since these can help with risk reduction measurements if any contamination is detected, such as the rebalancing of the laboratory ventilation systems [8].

\subsubsection{Industry}

The personal protective equipment that should be used in industry is similar to the laboratory. However, in the industry, the work periods with nanomaterials are longer and they use higher quantities 
of nanomaterials in their products, the exposure is higher. Therefore, it is necessary to take into account that the following should be additionally used $[90,91,94,95]$ :

- A powered air respirator, because ensures better comfort for longer work periods (it is recommended this system if the work lasts over $2 \mathrm{~h}$ ). However, for shorter periods of exposure a P3 filtering mask can be used.

- Similar to the laboratories, it should be used two or more pairs of disposable gloves (nitrile, vinyl, latex, Neoprene ${ }^{\circledR}$ ), but they should be replaced with higher frequency.

\subsection{Training}

Education and training are important tools for informing workers about hazards and protection measures to ensure their safety and their performance.

In training, an aspect not always considered, is Prevention through Design (PtD), i.e., the concept of Design with the objective to rule out occupational hazards to protect workers [74]. Hence, it is recommended to include the former concept in educational and training packages.

\subsubsection{Laboratory}

Before having to work with nanomaterials, all laboratory workers should undergo pertinent training, in which they learn about health issues related to the use of these particles, standard procedures for manipulating these materials and precautions to prevent exposure, hygiene requirements, and what should be done in case of incident handlings [92]. All of these safe work instructions should also be documented in a regularly updated and revised document, written in a clear and concise manner, in order to allow all users (especially new ones) to be aware of all the risks associated with these materials and all the procedures for safe handling and laboratory cleaning [8].

The training should be firstly basic training for the laboratory practice. Then, it must be complemented with continuous training about nano manipulation, since regular discoveries are made regarding the use and safety issues of these materials. Besides, the training should be complemented with written working procedures [90].

\subsubsection{Industry}

It is suggested [61] as a best practice that workers potentially exposed to manufactured nanomaterials (MNMs) should be educated on their risks and trained in how they can best manage the risks and protect themselves. Besides following current guidelines, education and training should focus on those aspects of manufactured nanomaterials that are additional to, or different from, education and training in the safe handling of bulk material chemicals. Hence, the following topics should be included [61]:

- Hazards are specific to MNMs and different from the bulk material.

- Hazard classes are assigned to MNMs.

- Routes of exposure are important which workplace exposures have been measured and which tasks put workers most at risk.

- How proposed OELs can be interpreted.

- When and how control banding, specific controls and PPE for MNMs can be used.

Normally, the workers face unknown risks regarding the exposure to nanomaterials, since the legislation considered that the risks of nanomaterials are the same as the micro materials. So, a deeper worker education and training initiatives are needed to prepare the nanotechnology workforce as the field continues to develop. Similar training that is used for laboratories should be performed, although with more frequency and the written working procedures should be regularly updated $[90,96]$. 


\subsection{Maintenance}

Regular maintenance is essential to ensure safety and reliability of the workplace, since the lack of maintenance can lead to dangerous situations, accidents and health problems.

\subsubsection{Laboratory}

In the laboratories maintenance activities, the workers should [90,97]:

- Perform the separation of the laboratory clothes from the outside ones (compulsory).

- Use safety containers for transportation of nanomaterials.

- Store in specific areas and separate cabins the nanomaterials. These cabinets must carry an appropriate danger label.

- The workers that handle the nanomaterials in the laboratory should be the ones that cleans the laboratory.

- The cleaning process should be wet to avoid the dispersion to the working atmosphere of the nanoparticles.

- The residues should be treated as chemical/hazardous waste and deposited in double bagging with a label that indicates the presence of nanomaterials in those wastes and include available information characterizing known and suspected properties.

- In the case that nanoparticles are accidentally split, the workplace must be cleaned immediately with a wet damp towel. Under no circumstances may residual materials be blown off the surface, particularly in the case of nanomaterials.

- Use the same protective equipment's during the cleaning and maintenance activities.

- Laboratory responsible must supervise the cleaning and maintenance activities.

\subsubsection{Industry}

In the industry, the same maintenance procedures that are used in the laboratories should be adopted [90]. It should be considered that maintenance and cleaning operations may generate aerosols and workplace contamination increasing the risk of exposures for workers. During preventive maintenance, it is likely that safety devices (such as filtration elements) are "disconnected", which means the workers are immediately exposed if an error occurs. This implies a high risk of exposure that must be managed with well trained workers [33].

\subsection{Application of Safety Guidelines}

To enforce the implementation of the safety guidelines, inspections should be conducted in parallel with other control actions.

\subsubsection{Laboratory}

Besides regular inspections made by a health and safety specialist, to ensure the application of the safety guidelines in the laboratories the following measures should be also applied [86]:

- $\quad$ Restricted access to the room (magnetic card access control system)

- Evidence about exposed people + board to record presence

- Medical surveillance to all persons that works with nanomaterials (once a year).

\subsubsection{Industry}

In industry, procedures similar to laboratories should be adopted, although besides the regular inspections, annual audits should be also performed and the medical surveillance should be carried out twice per year to all workers that handle nanomaterials [86].

Table 6 presents the proposed Occupational Exposure Limit Values for MNMs. 
Table 6. Proposed Occupational Exposure Limit Values for MNMs Adapted from [61].

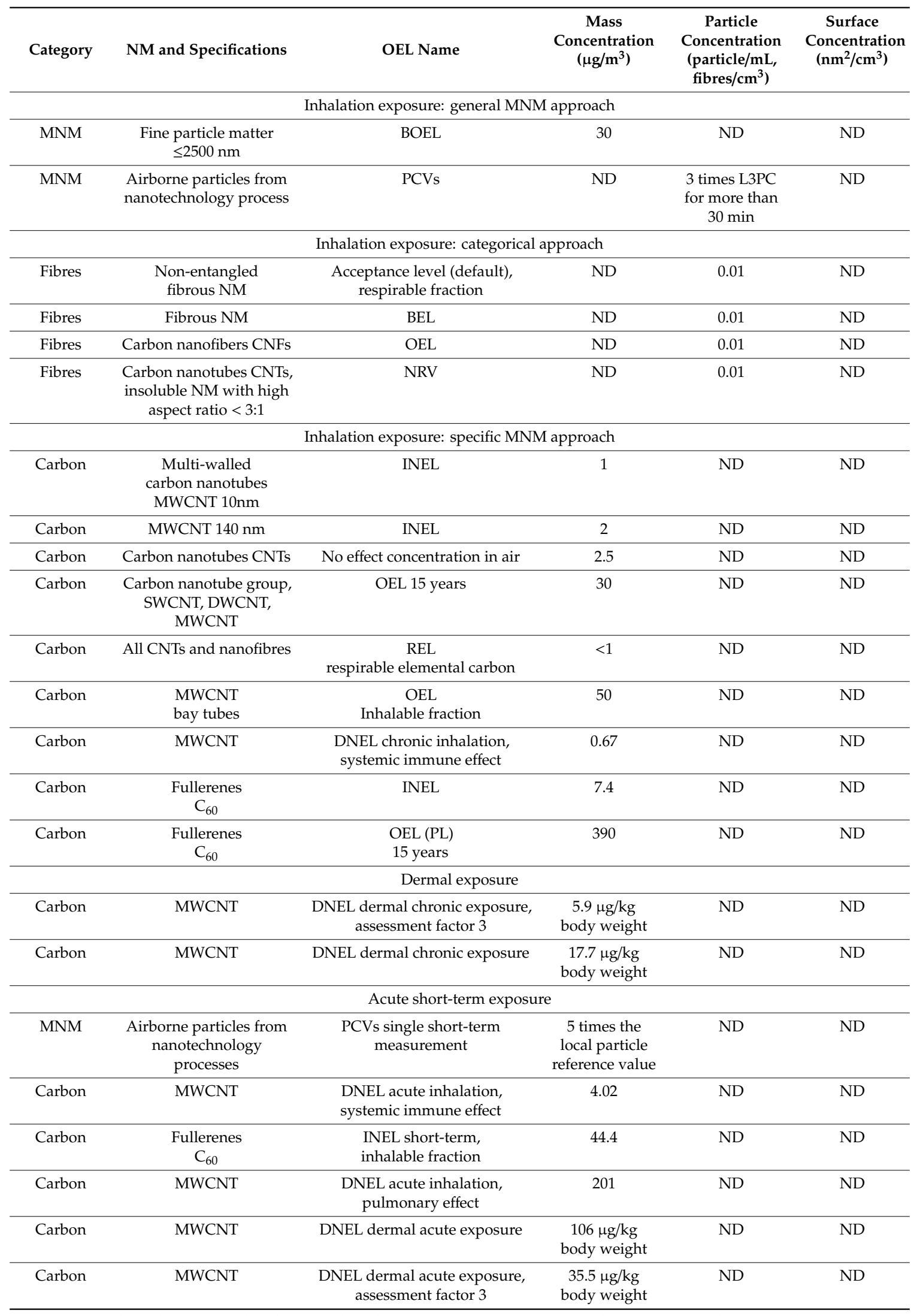

BEL: benchmark exposure level; BOEL: benchmark occupational exposure level; BSI: British Standards Institute; CNF: carbon nanofiber; CNT: carbon nanotube; DNEL: derived no-effect level; DWCNT: double-walled carbon nanotube; INEL: indicative no-effect level; MNM: manufactured nanomaterial; MWCNT: multi-walled carbon nanotube; ND: no data; NM: nanomaterial; NRV: nano reference value; OEL (PL): occupational exposure limit period-limited; OEL: occupational exposure limit; PCVs: particle control values; REL: recommended exposure limit; SWCNT: single-walled carbon nanotube. 
Other exposure limits can be identified. For instance, a REL of $1 \mu \mathrm{g} / \mathrm{m}^{3} \mathrm{EC}$ for CNTs and carbon nanofibers is proposed as an $8 \mathrm{~h}$ TWA respirable mass concentration [5,56]. BSI [63] suggested a BEL of 0.01 fibres $/ \mathrm{cm}^{3}$ and this has been established in UK, Germany and Switzerland [5,98].

\subsection{Product Life Cycle}

Research, development, and manufacturing of products with nanomaterials must take the responsibility of environmental, safety and health impact of products at specific points during the life cycle of the material from design up to disposal. In other words, they must assume product stewardship. Safety data sheets must be provided and health and communication standards followed. Besides product and hazards identification, composition, first-aid fire-fighting and accidental release measures, handling and storage, properties (physical and chemical), stability and reactivity, Product Stewardship may also include ecological, toxicological, disposal and transport information $[80,99,100]$. Moreover, it is equally important to include product safety testing, correct labelling, dangerous issues during transportation, as well as a customer service.

\section{Conclusions}

Up to now, there is not enough knowledge on the possible adverse effects of CNTs and nano graphene to ensure a complete workplace safety. Considering that CNTs and nano graphene are increasingly used, and it is unlikely that in the near future, scientific and industrial entities stop using nano-modified products, it is imperative to establish guidelines to handle these materials.

The identification of the potential hazards of CNTs and graphene to human health, during the development of products with these materials, is imperative. Moreover, manufacturing "safe" end products containing these nanomaterials will enhance the confidence of end-users, workers, researchers and other relevant stakeholders.

In the present research work, some practical and simple safety and health management actions, (such as technical, PPE, training, maintenance, application of safety guidelines and product life cycle measures) for laboratories and industries that use nanomaterials in their workplaces, based on the current state of knowledge, are proposed. These should be easily updated when more scientific data will become available. Monitoring, adaptation, control, and review of measures in place have a high importance.

Owing to an insufficient knowledge and application of the precautionary approach in practically all methodologies for management of CNTs and nano graphene safety currently available, proactive measures have an 'over-protection', that probably will be softened as knowledge will increase, are generally better than having an insufficient protection; this environment has an important role in educating people.

Thus, more research and collaborative efforts on nano safety are required in order to prevent, minimize the potential hazards of nanomaterials and to fill the existing gaps.

Finally, to overcome health and safety concerns related with CNT and graphene products it should be use Prevention, Precaution and Proactivity (in case of uncertainty go beyond what is commonly required) measures. Above all, Design Integrating Safety, Sustainability and Salubrity (DI3S) should be applied as soon as possible in the product development industries; to safeguard that the manufacture CNTs and graphene products do not have negative impacts in the health and safety of the workers, consumers and environment, making possible for the companies to achieve a truly safe and sustainable management.

Funding: This work has received funding from the European Union's Horizon 2020 research and innovation program SMARTFAN under grant agreement No. 760779. IPC authors wish to acknowledge "National Funds through FCT—Portuguese Foundation for Science and Technology, References UIDB/05256/2020 e UIDP/05256/2020; Tânia Peixoto acknowledges the financial support from FCT, through the PhD Grant PD/BD/143035/2018.

Conflicts of Interest: The authors declare no conflict of interest. 


\section{References}

1. Sousa, S.P.B.; Santos, R.M.; Rocha, N. Smart carbon fibre reinforced polymer (CFRP) composites with carbon allotropes: A brief reflection on potential safety and health issues. In Proceedings of the International Symposium on Occupational Safety and Hygiene SHO 2019, Guimarães, Portugal, 15-16 April 2019.

2. Brasinika, D.; Kyriakidou, K.; Sousa, S.P.B.; Rocha, N.; Koumoulos, E.P.; Charitidis, C.A. Health and Safety Issues in the Development of (nano) carbon-based materials and composites: The case of novel multifunctional carbon fibre reinforced polymer composites. In Proceedings of the International Symposium on Occupational Safety and Hygiene SHO 2019, Guimarães, Portugal, 15-16 March 2018.

3. Wan, B.; Hou, J.; Guo, L.-H. Safety of Carbon Nanotubes. In Industrial Applications of Carbon Nanotubes; Elsevier: Amsterdam, The Netherlands, 2017; pp. 405-431.

4. Narei, H.; Ghasempour, R.; Akhavan, O. Toxicity and Safety Issues of Carbon Nanotubes. In Carbon Nanotube-Reinforced Polymers; Rafiee, R., Ed.; Elsevier: Amsterdam, The Netherlands, 2018; pp. 145-171. [CrossRef]

5. Guseva Canu, I.; Batsungnoen, K.; Maynard, A.; Hopf, N.B. State of knowledge on the occupational exposure to carbon nanotubes. Int. J. Hyg. Environ. Health 2020, 225, 113472. [CrossRef] [PubMed]

6. Lee, K.-T.; Park, D.H.; Baac, H.W.; Han, S. Graphene-and carbon-nanotube-based transparent electrodes for semitransparent solar cells. Materials 2018, 11, 1503. [CrossRef] [PubMed]

7. Searl, A.; Crawford, J. Review of Health Risks for Workers in the Waste and Recycling Industry; Institute of Occupational Medicine: London, UK, 2012.

8. Mohan, V.B. Handling and Risk Mitigation of Nanoscale Graphene and Related Materials: Some Considerations and Recommendations. C-J. Carbon Res. 2019, 5, 36. [CrossRef]

9. Ye, R.; Tour, J.M. Graphene at Fifteen. ACS Nano 2019, 13, 10872-10878. [CrossRef]

10. Novello, A.M.; Buitrago, E.; Groso, A.; Meyer, T. Efficient management of nanomaterial hazards in a large number of research laboratories in an academic environment. Saf. Sci. 2020, 121, 158-164. [CrossRef]

11. Freeland, J.; Hulme, J.; Kinnison, D.; Mitchell, A.; Veitch, P.; Aitken, R.; Hankin, S.; Poland, C.; Bard, D.; Gibson, R.; et al. Working Safely with Nanomaterials in Research \& Development; The UK NanoSafety Partnership Group: Edinburgh, UK, 2012.

12. Savolainen, K. Nanosafety in Europe 2015-2025: Towards Safe and Sustainable Nanomaterials and Nanotechnology Innovations; Finnish Institute of Occupational Health: Helsinki, Finland, 2013.

13. Geim, A.K.; Novoselov, K.S. The rise of graphene. Nat. Mater. 2007, 6, 183-191. [CrossRef]

14. Jeevanandam, J.; Barhoum, A.; Chan, Y.S.; Dufresne, A.; Danquah, M.K. Review on nanoparticles and nanostructured materials: History, sources, toxicity and regulations. Beilstein J. Nanotechnol. 2018, 9, 1050-1074. [CrossRef]

15. Zhou, Y.; Pervin, F.; Jeelani, S.; Mallick, P.K. Improvement in mechanical properties of carbon fabric-epoxy composite using carbon nanofibers. J. Mater. Process. Technol. 2008, 198, 445-453. [CrossRef]

16. Chen, Q.; Wu, W.; Zhao, Y.; Xi, M.; Xu, T.; Fong, H. Nano-epoxy resins containing electrospun carbon nanofibers and the resulting hybrid multi-scale composites. Compos. Part B Eng. 2014, 58, 43-53. [CrossRef]

17. Barua, B.; Saha, M.C. Ultrasound assisted hybrid carbon epoxy composites containing carbon nanotubes. J. Eng. Mater. Technol. 2013, 135. [CrossRef]

18. Godara, A.; Mezzo, L.; Luizi, F.; Warrier, A.; Lomov, S.V.; van Vuure, A.W.; Gorbatikh, L.; Moldenaers, P.; Verpoest, I. Influence of carbon nanotube reinforcement on the processing and the mechanical behaviour of carbon fiber/epoxy composites. Carbon 2009, 47, 2914-2923. [CrossRef]

19. Üstün, T.; Ulus, H.; Karabulut, S.E.; Eskizeybek, V.; Şahin, Ö.S.; Avc1, A.; Demir, O. Evaluating the effectiveness of nanofillers in filament wound carbon/epoxy multiscale composite pipes. Compos. Part B Eng. 2016, 96, 1-6. [CrossRef]

20. Hawkins, D.A., Jr.; Haque, A. Fracture toughness of carbon-graphene/epoxy hybrid nanocomposites. Procedia Eng. 2014, 90, 176-181. [CrossRef]

21. Hossain, M.K.; Chowdhury, M.M.R.; Bolden, N.W. Optimized Mechanical Performance of Carbon Fiber-Epoxy Composite Using Amino-Functionalized Graphene Nanoplatelets. In Proceedings of the ASME International Mechanical Engineering Congress and Exposition, Houston, TX, USA, 13-19 November 2015; p. V009T012A057. 
22. Qin, W.; Vautard, F.; Drzal, L.T.; Yu, J. Mechanical and electrical properties of carbon fiber composites with incorporation of graphene nanoplatelets at the fiber-matrix interphase. Compos. Part B Eng. 2015, 69, 335-341. [CrossRef]

23. Dahm, M.M.; Schubauer-Berigan, M.K.; Evans, D.E.; Birch, M.E.; Bertke, S.; Beard, J.D.; Erdely, A.; Fernback, J.E.; Mercer, R.R.; Grinshpun, S.A. Exposure assessments for a cross-sectional epidemiologic study of US carbon nanotube and nanofiber workers. Int. J. Hyg. Environ. Health 2018, 221, 429-440. [CrossRef]

24. Gurkan, I.; Cebeci, H. An approach to identify complex CNT reinforcement effect on the interlaminar shear strength of prepreg composites by Taguchi method. Compos. Struct. 2016, 141, 172-178. [CrossRef]

25. Dehghan, M.; Al-Mahaidi, R.; Sbarski, I. Investigation of CNT modification of epoxy resin in CFRP strengthening systems. Polym. Compos. 2016, 37, 1021-1033. [CrossRef]

26. Santos, R.M.; Vale, D.; Rocha, J.; Martins, C.; Mould, S.T.; Rocha, N. Multiscale carbon fibre-reinforced polymer (CFRP) composites containing carbon nanotubes with tailored interfaces. Fatigue Fract. Eng. Mater. Struct. 2019, 42, 1521-1533. [CrossRef]

27. Thostenson, E.T.; Li, W.Z.; Wang, D.Z.; Ren, Z.F.; Chou, T.W. Carbon nanotube/carbon fiber hybrid multiscale composites. J. Appl. Phys. 2002, 91, 6034-6037. [CrossRef]

28. Srivastava, S.K.; Mittal, V. Hybrid Nanomaterials: Advances in Energy, Environment, and Polymer Nanocomposites; John Wiley \& Sons: Hoboken, NJ, USA, 2017.

29. Thostenson, E.T.; Chou, T.-W. Processing-structure-multi-functional property relationship in carbon nanotube/epoxy composites. Carbon 2006, 44, 3022-3029. [CrossRef]

30. Salam, H.; Dong, Y.; Davies, I.J.; Pramanik, A. The effects of material formulation and manufacturing process on mechanical and thermal properties of epoxy/clay nanocomposites. Int. J. Adv. Manuf. Technol. 2016, 87, 1999-2012. [CrossRef]

31. Anand, A.; Joshi, M. Structural Composites Hybridized with Nanofillers: An Overview. J. Indian Inst. Sci. 2015, 95, 233-247.

32. Qian, H.; Greenhalgh, E.S.; Shaffer, M.S.P.; Bismarck, A. Carbon nanotube-based hierarchical composites: A review. J. Mater. Chem. 2010, 20, 4751-4762. [CrossRef]

33. Fleury, D.; Bomfim, J.A.S.; Vignes, A.; Girard, C.; Metz, S.; Muñoz, F.; R’Mili, B.; Ustache, A.; Guiot, A.; Bouillard, J.X. Identification of the main exposure scenarios in the production of CNT-polymer nanocomposites by melt-moulding process. J. Clean. Prod. 2013, 53, 22-36. [CrossRef]

34. Kausar, A.; Rafique, I.; Muhammad, B. Electromagnetic Interference Shielding of Polymer/Nanodiamond, Polymer/Carbon Nanotube, and Polymer/Nanodiamond-Carbon Nanotube Nanobifiller Composite: A Review. Polym.-Plast. Technol. Eng. 2017, 56, 347-363. [CrossRef]

35. Osada, R.; Suzuki, K. Development of a Flexible Tactile Sensor Using Area-Arrayed Bundle Structures of Multi-Walled Carbon Nanotubes. In Proceedings of the ASME 2018 International Mechanical Engineering Congress and Exposition, Pittsburgh, PA, USA, 9-15 November 2018.

36. Beaumont, P.W.; Soutis, C.; Hodzic, A. The Structural Integrity of Carbon Fiber Composites; Springer: Berlin/Heidelberg, Germany, 2017.

37. Khan, S.U.; Kim, J.-K. Impact and delamination failure of multiscale carbon nanotube-fiber reinforced polymer composites: A review. Int. J. Aeronaut. Space Sci. 2011, 12, 115-133. [CrossRef]

38. Lubineau, G.; Rahaman, A. A review of strategies for improving the degradation properties of laminated continuous-fiber/epoxy composites with carbon-based nanoreinforcements. Carbon 2012, 50, 2377-2395. [CrossRef]

39. Tang, Y.H.; Ye, L.; Zhang, Z.; Friedrich, K. Interlaminar fracture toughness and CAI strength of fibre-reinforced composites with nanoparticles-A review. Compos. Sci. Technol. 2013, 86, 26-37. [CrossRef]

40. StatNano. Nanomaterials and Morphologies. Available online: https://statnano.com/nanomaterials (accessed on 20 July 2020).

41. Comfort, K.K. The rise of nanotoxicology: A successful collaboration between engineering and biology. AIMS Bioeng. 2016, 3, 230. [CrossRef]

42. Emerce, E.; Ghosh, M.; Öner, D.; Duca, R.-C.; Vanoirbeek, J.; Bekaert, B.; Hoet, P.H.; Godderis, L. Carbon Nanotube-and Asbestos-Induced DNA and RNA Methylation Changes in Bronchial Epithelial Cells. Chem. Res. Toxicol. 2019, 32, 850-860. [CrossRef]

43. Gangoli, V.S.; Raja, P.M.V.; Esquenazi, G.L.; Barron, A.R. The safe handling of bulk low-density nanomaterials. SN Appl. Sci. 2019, 1, 644. [CrossRef] 
44. Chakraborty, G.; Valapa, R.B.; Pugazhenthi, G.; Katiyar, V. Investigating the properties of poly (lactic acid)/exfoliated graphene based nanocomposites fabricated by versatile coating approach. Int. J. Biol. Macromol. 2018, 113, 1080-1091. [CrossRef] [PubMed]

45. Pelin, M.; Sosa, S.; Prato, M.; Tubaro, A. Occupational exposure to graphene based nanomaterials: Risk assessment. Nanoscale 2018, 10, 15894-15903. [CrossRef] [PubMed]

46. Facciolà, A.; Visalli, G.; La Maestra, S.; Ceccarelli, M.; D’Aleo, F.; Nunnari, G.; Pellicanò, G.F.; Di Pietro, A. Carbon nanotubes and central nervous system: Environmental risks, toxicological aspects and future perspectives. Environ. Toxicol. Pharmacol. 2019, 65, 23-30. [CrossRef]

47. Koppens, F.; Coleman, J.; Morandi, V.; Tredicucci, A. Science and technology roadmap for graphene, related two-dimensional crystals, and hybrid systems. Nanoscale 2015, 7, 4598-4810.

48. Bianco, A.; Prato, M. Safety concerns on graphene and 2D materials: A Flagship perspective. 2d Mater. 2015, 2, 30201. [CrossRef]

49. Sardoiwala, M.N.; Kaundal, B.; Choudhury, S.R. Toxic impact of nanomaterials on microbes, plants and animals. Environ. Chem. Lett. 2018, 16, 147-160. [CrossRef]

50. Selvaraj, K.; Gowthamarajan, K.; Karri, V.V.S.R. Nose to brain transport pathways an overview: Potential of nanostructured lipid carriers in nose to brain targeting. Artif. CellsNanomed. Biotechnol. 2018, 46, 2088-2095. [CrossRef]

51. Giusti, A.; Atluri, R.; Tsekovska, R.; Gajewicz, A.; Apostolova, M.D.; Battistelli, C.L.; Bleeker, E.A.J.; Bossa, C.; Bouillard, J.; Dusinska, M.; et al. Nanomaterial grouping: Existing approaches and future recommendations. NanoImpact 2019, 16, 100182. [CrossRef]

52. Cao, Y.; Luo, Y. Pharmacological and toxicological aspects of carbon nanotubes (CNTs) to vascular system: A review. Toxicol. Appl. Pharmacol. 2019, 385, 114801. [CrossRef]

53. Bonner, J.C. Nanoparticles as a potential cause of pleural and interstitial lung disease. Proc. Am. Thorac. Soc. 2010, 7, 138-141. [CrossRef] [PubMed]

54. Ryman-Rasmussen, J.P.; Tewksbury, E.W.; Moss, O.R.; Cesta, M.F.; Wong, B.A.; Bonner, J.C. Inhaled multiwalled carbon nanotubes potentiate airway fibrosis in murine allergic asthma. Am. J. Respir. Cell Mol. Biol. 2009, 40, 349-358. [CrossRef] [PubMed]

55. Loos, M. Carbon Nanotube Reinforced Composites: CNT Polymer Science and Technology; Elsevier: Amsterdam, The Netherlands, 2014.

56. NIOSH. Current Intelligence Bulletin 65: Occupational Exposure to Carbon Nanotubes and Nanofibers; Department of Health and Human Services, Public Health Service, Center for Disease Control and Prevention, National Institute for Occupational Safety and Health DHHS (NIOSH): Cincinnati, OH, USA, 2013.

57. Gaffet, E. NanoMaterials \& Responsible Development How to conciliate Research, Innovation and Safety. In Proceedings of the Nanotechitaly 2011, Venice, Italy, 28-30 November 2011.

58. Aitken, R.; Hankin, S.; Ross, B.; Tran, C.; Stone, V.; Fernandes, T.; Donaldson, K.; Duffin, R.; Chaudhry, Q.; Wilkins, T. EMERGNANO: A Review of Completed and Near Completed Environment, Health and Safety Research on Nanomaterials and Nanotechnology Defra Project CB0409; Report TM/09/01; Institute of Occupational Medicine: Edinburgh, UK, 2009.

59. Dazon, C.; Witschger, O.; Bau, S.; Fierro, V.; Llewellyn, P.L. Toward an operational methodology to identify industrial-scaled nanomaterial powders with the volume specific surface area criterion. Nanoscale Adv. 2019, 1, 3232-3242. [CrossRef]

60. Sousa, S.P.; Baptista, J.S.; Ribeiro, M. Polymer nano and submicro composites risk assessment. Int. J. Work. Cond. 2014, 7, 103-119.

61. World Health Organization. WHO Guidelines on Protecting Workers from Potential Risks of Manufactured Nanomaterials; World Health Organization: Geneva, Switzerland, 2017.

62. Silva, F.; Sousa, S.; Arezes, P.; Swuste, P.; Ribeiro, M.; Baptista, J.S. Qualitative risk assessment during polymer mortar test specimens preparation-methods comparison. J. Phys. Conf. Ser. 2015, 617, 12037. [CrossRef]

63. Nanotechnologies-Part, B. 2: Guide to Safe Handling and Disposal of Manufactured Nanomaterials; PD 6699-2-2007; British Standards Institution: London, UK, 2007.

64. CDC. NIOSH: Nanotechnology_Field Studies Effort. Available online: https://www.cdc.gov/niosh/topics/ nanotech/field.html (accessed on 17 June 2020).

65. Wohlleben, W.; Hellack, B.; Nickel, C.; Herrchen, M.; Hund-Rinke, K.; Kettler, K.; Riebeling, C.; Haase, A.; Funk, B.; Kühnel, D. The nanoGRAVUR framework to group (nano) materials for their occupational, 
consumer, environmental risks based on a harmonized set of material properties, applied to 34 case studies. Nanoscale 2019, 11, 17637-17654. [CrossRef]

66. European Commission. Regulation (EC) No 1907/2006 of the European Parliament and of the Council of 18 December 2006 concerning the Registration, Evaluation, Authorisation and Restriction of Chemicals (REACH), establishing a European Chemicals Agency, amending Directive 1999/45/EC and repealing Council Regulation (EEC) No 793/93 and Commission Regulation (EC) No 1488/94 as well as Council Directive 76/769/EEC and Commission Directives 91/155/EEC, 93/67/EEC, 93/105/EC and 2000/21/EC. Off. J. Eur. Union 2006, 396, 1-849.

67. ECHA. Read-Across Assessment Framework (RAAF); European Chemicals Agency: Helsinki, Finland, 2017.

68. Schimpel, C.; Resch, S.; Flament, G.; Carlander, D.; Vaquero, C.; Bustero, I.; Falk, A. A methodology on how to create a real-life relevant risk profile for a given nanomaterial. J. Chem. Health Saf. 2018, 25, 12-23. [CrossRef]

69. Sweet, L.; Strohm, B. Nanotechnology-Life-cycle risk management. Hum. Ecol. Risk Assess. 2006, 12, 528-551. [CrossRef]

70. Lövestam, G.; Rauscher, H.; Roebben, G.; Klüttgen, B.S.; Gibson, N.; Putaud, J.-P.; Stamm, H. Considerations on a definition of nanomaterial for regulatory purposes. Jt. Res. Cent. (JRC) Ref. Rep. 2010, 80, 1-41.

71. Roes, L.; Patel, M.K.; Worrell, E.; Ludwig, C. Preliminary evaluation of risks related to waste incineration of polymer nanocomposites. Sci. Total Environ. 2012, 417, 76-86. [CrossRef] [PubMed]

72. Wardak, A.; Gorman, M.E.; Swami, N.; Deshpande, S. Identification of risks in the life cycle of nanotechnology-based products. J. Ind. Ecol. 2008, 12, 435-448. [CrossRef]

73. Gupta, J.; Hendershot, D.; Mannan, M. The real cost of process safety-A clear case for inherent safety. Process Saf. Environ. Prot. 2003, 81, 406-413. [CrossRef]

74. Hodson, L.L.; Geraci, C.L. Chapter 11-Managing nanotechnology risks in small business-A National Institute for Occupational Safety and Health Perspectiv. In Nanotechnology Environmental Health and Safety; Elsevier: Amsterdam, The Netherlands, 2018; pp. 251-280. [CrossRef]

75. Jaurand, M.-C.F.; Renier, A.; Daubriac, J. Mesothelioma: Do asbestos and carbon nanotubes pose the same health risk? Part. Fibre Toxicol. 2009, 6, 16. [CrossRef] [PubMed]

76. Laux, P.; Tentschert, J.; Riebeling, C.; Braeuning, A.; Creutzenberg, O.; Epp, A.; Fessard, V.; Haas, K.-H.; Haase, A.; Hund-Rinke, K. Nanomaterials: Certain aspects of application, risk assessment and risk communication. Arch. Toxicol. 2018, 92, 121-141. [CrossRef]

77. Donaldson, K.; Poland, C.; Bonner, J.; Duffin, R. The Toxicology of Carbon Nanotubes; Cambridge University Press: Cambridge, UK, 2012.

78. Bussy, C.; Ali-Boucetta, H.; Kostarelos, K. Safety considerations for graphene: Lessons learnt from carbon nanotubes. Acc. Chem. Res. 2013, 46, 692-701. [CrossRef] [PubMed]

79. Lee, Y.S.; Sung, J.H.; Song, K.S.; Kim, J.K.; Choi, B.S.; Yu, I.J.; Park, J.D. Derivation of occupational exposure limits for multi-walled carbon nanotubes and graphene using subchronic inhalation toxicity data and a multi-path particle dosimetry model. Toxicol. Res. 2019, 8, 580-586. [CrossRef]

80. OECD. OECD Countries Address the Safety of Manufactured Nanomaterials. Available online: https: //www.oecd.org/chemicalsafety/oecd-countries-address-the-safety-of-manufactured-nanomaterials.htm (accessed on 17 June 2020).

81. Iyiegbuniwe, E.A.; Nwosu, U.U.; Kodali, S. A Review of Occupational Health Implications of Exposure and Risk Management of Carbon Nanotubes and Carbon Nanofibers. Int. J. Environ. Sci. Dev. 2016, 7, 849. [CrossRef]

82. Schulte, P.; Kuempel, E.; Drew, N. Characterizing risk assessments for the development of occupational exposure limits for engineered nanomaterials. Regul. Toxicol. Pharmacol. 2018, 95, 207-219. [CrossRef]

83. Firme, C.P., III; Bandaru, P.R. Toxicity issues in the application of carbon nanotubes to biological systems. Nanomed: Nanotechnol. Biol. Med. 2010, 6, 245-256. [CrossRef]

84. Dahm, M.M.; Evans, D.E.; Schubauer-Berigan, M.K.; Birch, M.E.; Fernback, J.E. Occupational exposure assessment in carbon nanotube and nanofiber primary and secondary manufacturers. Ann. Occup. Hyg. 2012, 56, 542-556. [PubMed]

85. Chen, M.; Zhou, S.; Zhu, Y.; Sun, Y.; Zeng, G.; Yang, C.; Xu, P.; Yan, M.; Liu, Z.; Zhang, W. Toxicity of carbon nanomaterials to plants, animals and microbes: Recent progress from 2015-present. Chemosphere 2018, 206, 255-264. [CrossRef] [PubMed] 
86. European Comission. Employment, Social Affairs \& Inclusion, Guidance on the Protection of the Health and Safety of Workers from the Potential Risks Related to Nanomaterials at Work; European Comission: Brussels, Belgium, 2013.

87. NANO. Resources for Nanotechnology Laboratory Safety. Available online: https://www.nano.gov/LabSafety (accessed on 20 May 2020).

88. Kumar, N.; Kumbhat, S. Chapter 11-Toxicity and Environmental Issues. In Essentials in Nanoscience and Nanotechnology; John Wiley \& Sons: Hoboken, NJ, USA, 2016; pp. 447-448.

89. Hallock, M.F.; Greenley, P.; DiBerardinis, L.; Kallin, D. Potential risks of nanomaterials and how to safely handle materials of uncertain toxicity. J. Chem. Health Saf. 2009, 16, 16-23. [CrossRef]

90. Groso, A.; Petri-Fink, A.; Rothen-Rutishauser, B.; Hofmann, H.; Meyer, T. Engineered nanomaterials: Toward effective safety management in research laboratories. J. Nanobiotechnology 2016, 14, 21. [CrossRef] [PubMed]

91. Golanski, L.; Guiot, A.; Rouillon, F.; Pocachard, J.; Tardif, F. Experimental evaluation of personal protection devices against graphite nanoaerosols: Fibrous filter media, masks, protective clothing, and gloves. Hum. Exp. Toxicol. 2009, 28, 353-359. [CrossRef] [PubMed]

92. Dhasmana, A.; Firdaus, S.; Singh, K.P.; Raza, S.; Jamal, Q.M.S.; Kesari, K.K.; Rahman, Q.; Lohani, M. Nanoparticles: Applications, Toxicology and Safety Aspects. In Perspectives in Environmental Toxicology; Springer: Berlin/Heidelberg, Germany, 2017; pp. 47-70.

93. Park, M.V.; Bleeker, E.A.; Brand, W.; Cassee, F.R.; van Elk, M.; Gosens, I.; de Jong, W.H.; Meesters, J.A.; Peijnenburg, W.J.; Quik, J.T. Considerations for safe innovation: The case of Graphene. ACS Nano 2017, 11, 9574-9593. [CrossRef]

94. Bałazy, A.; Toivola, M.; Reponen, T.; Podgórski, A.; Zimmer, A.; Grinshpun, S.A. Manikin-based performance evaluation of N95 filtering-facepiece respirators challenged with nanoparticles. Ann. Occup. Hyg. 2006, 50, 259-269.

95. Dolez, P.; Vinches, L.; Wilkinson, K.; Plamondon, P.; Vu-Khanh, T. Development of a test method for protective gloves against nanoparticles in conditions simulating occupational use. J. Phys. Conf. Ser. 2011, 304, 12066. [CrossRef]

96. Schug, T.T.; Johnson, A.F.; Balshaw, D.M.; Garantziotis, S.; Walker, N.J.; Weis, C.; Nadadur, S.S.; Birnbaum, L.S. ONE Nano: NIEHS's strategic initiative on the health and safety effects of engineered nanomaterials. Environ. Health Perspect. 2013, 121, 410-414. [CrossRef]

97. Dhawan, A.; Shanker, R.; Das, M.; Gupta, K.C. Guidance for safe handling of nanomaterials. J. Biomed. Nanotechnol. 2011, 7, 218-224. [CrossRef]

98. Ellenbecker, M.; Tsai, S.; Jacobs, M.; Riediker, M.; Peters, T.; Liou, S.; Avila, A.; FossHansen, S. The difficulties in establishing an occupational exposure limit for carbon nanotubes. J. Nanoparticle Res. 2018, $20,131$. [CrossRef]

99. Boyes, W.K.; Thornton, B.L.M.; Al-Abed, S.R.; Andersen, C.P.; Bouchard, D.C.; Burgess, R.M.; Hubal, E.A.C.; Ho, K.T.; Hughes, M.F.; Kitchin, K. A comprehensive framework for evaluating the environmental health and safety implications of engineered nanomaterials. Crit. Rev. Toxicol. 2017, 47, 771-814. [CrossRef] [PubMed]

100. Park, H.-G.; Yeo, M.-K. Nanomaterial regulatory policy for human health and environment. Mol. Cell. Toxicol. 2016, 12, 223-236. [CrossRef]

(C) 2020 by the authors. Licensee MDPI, Basel, Switzerland. This article is an open access article distributed under the terms and conditions of the Creative Commons Attribution (CC BY) license (http://creativecommons.org/licenses/by/4.0/). 